\title{
REGENERATION STATUS AND CARBON ACCUMULATION POTENTIAL IN COMMUNITY MANAGED SAL (Shorea robusta) FORESTS OF FAR-WESTERN TERAI REGION, NEPAL
}

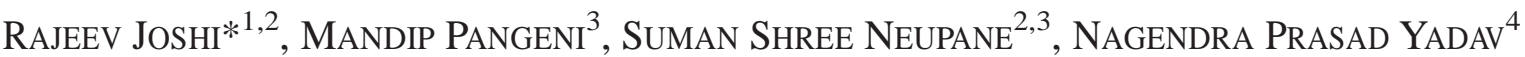 \\ ${ }^{1}$ Forest Research Institute (Deemed to be) University, Dehradun-248195, Uttarakhand, India \\ ${ }^{2}$ Faculty of Forestry, Amity Global Education (Lord Buddha College), CTEVT, Tokha-11, Kathman- \\ du-44600, Nepal \\ ${ }^{3}$ School of Forestry and Natural Resource Management, Institute of Forestry, Tribhuvan University, \\ Kathmandu-44618, Nepal \\ ${ }^{4}$ Forest and Environment Expert, Natural Resource and Environment Management Consultancy, \\ Dhapakhel-44703, Lalitpur-23, Nepal
}

*Corresponding author: joshi.rajeev20@gmail.com

ORCID: 0000-0003-1106-9911

\begin{abstract}
.
Regeneration patterns of species populations can address climate change by adaptive evolution or by migrating association to survival in their favorable climate and finally decide the particular forest future. This research examined the status of regeneration and carbon sequestration potential in the tropical Sal (Shorea robusta) forest of Kanchanpur district, Nepal. For the study, a total of 63 concentric sample plots were investigated by using systematic sampling with $0.5 \%$ sampling intensity. The regeneration status of the forest was estimated by calculating the density of each species in each developmental phase. The aboveground carbon stock of tree species was estimated using allometric equations. The studied forests had good regeneration status and Shorea robusta was the dominant species in terms of regeneration and carbon stock. Ramnagar community forest had a greater number of seedlings, saplings, and trees than that of the Ganesh community forest. Reverse J-shaped population curves were recorded at both the study sites. This study provided infor- mation about the regeneration status, structure, composition, and carbon sequestration potential of tree species which is very necessary for the conservation and sustainable management of community forests. Studies indicate that community management has increased the carbon stock of forests and also has promoted the productivity of forests by altering the structure and composition of the community forests.
\end{abstract}

Key words: aboveground biomass, diameter at breast height, forest management, natural regeneration, seedlings

\section{INTRODUCTION}

Forests are important repositories of terrestrial biodiversity and play a key role in influencing socio-ecological and cultural attributes of human societies including livelihood activities of traditional societies living in these areas (Hermann, 2006; Baboo et al. 2017; Karki et al. 2017). Biodiversity is needed for human survival economic well-being, and ecosystem function and stability (Singh, 2002). Globally, habitat destruction, overexploitation, pollution, and species introduction are identified as major causes of biodiversity loss (UNEP, 2001; Bargali et al. 2014, 2015; Mourya et al. 2019). The existence of a species in nature largely depends on its regeneration under varied environmental conditions like forest floor conditions; nutrient use efficiency of species and cycling as well as decomposition processes
(Bargali, 1994, 1995, 1996; Bargali et al. 1992, 1993; Bargali and Singh, 1997). The regeneration of species dependent on environmental factors, soil conditions, anthropogenic pressures, and management practices.

The paradigm shift in the model of forest management in Nepal has been extraordinary and vaguely studied, where community-based forest management (CBFM) is one milestone Nepal has set in this arena. In the present context, $44.74 \%$ of Nepal's area is under forest cover and CBFM covers about 2.3 million hectares of forest, comprising $38.5 \%$ of the total forest in the country (MoFSC, 2015; Raj Pathak et al. 2017) which shows Nepal at the forefront of the CBFM practice making it a global success (Ojha et al. 2007). Nepal's community forest (a model of CBFM) which began in 1978 with a thorough necessity of a stable forestry sector with a connection of 
people to natural resources (Hobley, 1996; Acharya, 2002), after four decades has upgraded positively from centralized and top-down management to decentralized and participatory management regime with gradual development in the formulation of major national policies like National forest plan 1976, Master Plan for the Forestry Sector 1989, Forest Act 1993, Forest Rules 1995, and forest Policy 2015 \& 2019 (MoFSC, 1993; MoFSC, 1995; MoFE, 2019; Acharya, 2003). The regeneration and production function of a forest is characterized by the presence of different age group of seedlings, saplings, and trees (Chauhan et al. 2008) which later helps to understand the status of tree populations, regeneration, and diversity for the application of conservation measures (Mishra et al. 2014). Regeneration is a vital process for the existence of species in a community and studies have shown the effects of devolved forest management in Nepal as a general picture of forest conservation and regeneration (Khumbongmayum et al. 2005; Chhetri et al. 2012; Bhattarai \& Conway, 2008). Regeneration not only presents the recent status, health, and vitality of the forest but also show cases the future forest composition. It can be further used to determine whether forest management leads to productive capacity as well as biological diversity of forests are maintained (Awasthi et al. 2015; Malik \& Bhatt, 2016; Lutze et al. 2004). The intensity of management interventions applied differentiates the regeneration dynamics and species composition in forests which brings out the necessity of regular monitoring and examination of silvicultural interventions to ensure effective forest management on regeneration structure and composition as well as species diversity ( Awasthi et al. 2020; Awasthi et al. 2015; Figueroa Rangel \& Olvera-Vargas, 2000; Nguyen \& Baker, 2016). Foresters and ecologists see inadequate forest regeneration as a backdrop (Ceccon et al. 2004) which is generally influenced by locality factors and later changes viability of forest population (Condit et al. 1996; Stork, 2010; Mishra et al. 2013), local habitat characters (Chaturvedi et al. 2012), community composition, insects, disease, herbivores and competing vegetation (Sagar et. al., 2008; Ward et al. 2006).

Regeneration of disturbed forests and conservation of forests sequester a significant quantity of carbon in soil and vegetation layers (Brown et al. 1996) through which forests act as one of the largest carbon sinks helping control atmospheric $\mathrm{CO}_{2}$ concentrations (Zhou et al. 2006). Forests contain almost half of the terrestrial carbon (Dixon et al. 1994; IPCC, 2007; Wei et al. 2014; Singh et al. 2006), and on average carbon comprise ca. $50 \%$ of the dry biomass (Mac Dicken 1997). In Nepal, through pilot projects few CFUG's have got support and assistance from the government for carbon enhancement to mitigate and adapt against climate change and also to make carbon trade, a great hope in a country like Nepal (Chand et al. 2018; UNFCC, 2010; Adhikari, 2016). Carbon sequestration through sustainable forest management can be an effective way to cope with global climate change (Brown et al. 1996; IPCC, 1995). Therefore, we assessed the regeneration status of the community forests in Nepal and their potential to accumulate carbon through which we could have definite knowledge about the effects of forest management and silvicultural operations on the overall health and vitality of the forests. Thus, this study addresses the factors responsible for regeneration and carbon accumulation by a comparative study in two community-managed forests (CFs) of Far-Western Terai region which is lacking in the existing literature.

\section{MATERIALS AND METHODS}

\section{Study area}

The study was carried out in the natural mixed Sal (Shorea robusta) broad-leaved forest of Terai region which represents the foothills of Himalaya (Figure 1). The field study was carried out during the winter season between October and December 2018. We selected Ganesh (Bedkot Municipality) and Ramnagar (Belauri Municipality) community forests (CF) of Kanchanpur district for this purpose. Kanchanpur is a district located in the Far-Western Province of the southwestern part of Nepal $\left(28.8372^{\circ} \mathrm{N} ; 80.3213^{\circ} \mathrm{E}\right)$ (Bhatta and Joshi, 2020). The elevation of the district is moderately steep ranging from lower tropical below $300 \mathrm{~m}$ and upper tropical ranging from 300-1000 m.a.s.l. Ganesh CF with its dominant species i.e. Mallotus philippensis covers an area of 434.48 ha at 221-300 m..s.1. Similarly, Ramnagar CF consists of a natural Sal forest which covers an area of 197.16 ha at 120-145 m.a.s.1.. Other associate species such as Adina cordifolia, Anogeissus latifolia, Lagerstroemia parviflora, Schleichera oleosa, Pterocarpus marsupium, etc. were recorded from both study sites. The entire forest area was divided into different blocks and compartments by community forest user groups (CF manuals) based upon the geographical location 
and species composition. Ganesh CF was divided into three blocks and Ramnagar CF was divided into one compartment and eight sub-compartments with managerial and administrative motives. The average annual rainfall is $1512.12 \mathrm{~mm}$ and temperature ranges from 13 to $38^{\circ} \mathrm{C}$ (Joshi et al. 2021).

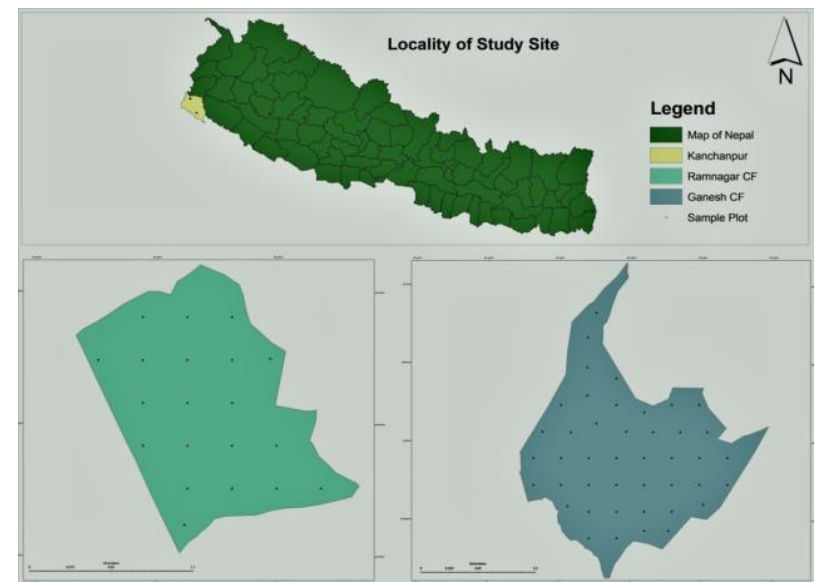

Figure 1: Map of the study area.

\section{Forest sampling design and measurement}

GPS and Arc Map 10.5 software were used to delineate the selected community forests. Systematic sampling with $0.5 \%$ sampling intensity was done. A total of 63 circular sample plots (43 sample plots in Ganesh and 20 in Ramnagar $\mathrm{CF}$ ), each of $500 \mathrm{~m}^{2}$, were established in both community forests was determined by the formula given as:

Number of sample plots $=\frac{\text { Area of } \mathrm{CF}\left(\mathrm{m}^{2}\right) \times \text { sampling intensity }(\%)}{\text { Area of sample plot }\left(\mathrm{m}^{2}\right) \times 100}$

In each sample plot, three concentric plots with radii of $12.62 \mathrm{~m}, 5.64$, and $1 \mathrm{~m}$ were used for sampling trees $(\mathrm{DBH} \geq 5 \mathrm{~cm})$, saplings $(\mathrm{DBH} 1-5 \mathrm{~cm})$, and seedlings $(\mathrm{DBH}<1 \mathrm{~cm})$ respectively. Regenerations (seedlings and saplings) were counted in the plot (MoFSC 2010), to obtain density. The height of each tree was determined by using a Silva clinometer and the diameter at breast height $(\mathrm{DBH})$ of each tree within the sample plot was measured by using diameter tape in a $12.62 \mathrm{~m}$ plot.

\section{Quantitative Analysis}

Regeneration density. The total numbers of saplings and trees were acquired from the number of individuals as recorded during carbon stock estimation considering individuals with DBH $<5 \mathrm{~cm}$ as saplings and trees as DBH $\geq 5 \mathrm{~cm}$ (DFRS, $2014 \mathrm{a}$, b; Maren et al. 2015). Likewise, entire seedlings of each species were also acquired from the number of individuals as recorded during carbon stock estimation considering individuals with $\mathrm{DBH}<1 \mathrm{~cm}$ (height between $15 \mathrm{~cm}$ to $137 \mathrm{~cm}$ ) as seedlings (DFRS, $2014 \mathrm{a}, \mathrm{b}$; Maren et al. 2015) which were counted in altogether 63 sample plots of $1 \mathrm{~m}$ radius. Finally, seedlings, saplings, and trees were counted in each sample plot and later the numbers counted were added, averaged, and recorded for density calculation. Density was estimated by the following equation:

Density $\left(\frac{\mathrm{no}}{\mathrm{ha}}\right)=\frac{\text { Total number of individuals in each life form }}{\text { Total no, of sample plots studied } \mathrm{x} \text { area of each plot }\left(\mathrm{m}^{2}\right)} \times 10000$

Similarly, the density of individual species was estimated by the following equation:

Density $\left(\frac{\text { no }}{\text { ha }}\right)=\frac{\text { Total number of individuals of each species in each life form }}{\text { Total no, of plots studied } x \text { area of each plot }\left(\mathrm{m}^{2}\right)} \times 10000$

Community attributes (Importance Value Index). For the quantitative data analysis, density, frequency, and basal area of tree species were calculated according to Zobel et al. (1987). To express the dominance and ecological success of any species, with a single value, the concept of Importance Value Index (I.V.I) has been developed and was calculated to determine the overall importance of each species in the community structure by adding the relative values of the three parameters i.e. density, frequency and basal area (Curtice et al. 1959).

$$
\text { I. V. I = R. D. + R. F. + R. B.A. }
$$

Where, I.V.I. $=$ Importance Value Index, RD $=$ Relative Density, R.F. $=$ Relative Frequency and R.B.A. = Relative Basal Area.

Biomass and carbon estimation: Aboveground trees biomass. For the estimation of biomass, a non-destructive method was chosen in the study. The aboveground tree biomass (AGTB) was calculated by using the allometric equation provided by Chave et al. (2005).

\section{$\mathrm{AGTB}=0.0509 \times \mathrm{D}^{2} \times \mathrm{WD} \times \mathrm{H}$}

where, WD = Wood specific density $\left(\mathrm{kg} \mathrm{m}^{-3}\right), \mathrm{D}=$ Tree diameter at breast height $(\mathrm{cm}), \mathrm{H}=$ Tree height (m) for trees (DBH $\geq 5 \mathrm{~cm})$ (Chave et al. 2005).

Carbon Stock of Species. The total carbon stock of individual tree species in the community forests was calculated by adding the density values of the whole forest for that particular species. The percentage contribution of carbon stock of each tree species 
in a forest was determined by taking the proportional sum of carbon stock per ha of all species present in the forest to the sum of carbon stock of a particular species on the same forest (Joshi et al. 2020). It was determined by the following equation:

Carbon stock of a tree species \%

$$
=\frac{\text { Sum of carbon stock of a particular tree species }(\text { ha })}{\text { Sum of carbon stock of all tree species }(\text { ha })} \times 100
$$

\section{Statistical analysis}

A two-way analysis of variance (ANOVA) test was performed to test the significance of differences between CFs, species, and their interaction. To estimate carbon stocks CF scale was applied, but to determine the species-wise total carbon stock among the common species of community forests, three analytical replications of each CFs were taken for analyses. Replications were randomly assigned to create an equal number of replications of both CFs, to overcome a problem of the uneven number of plots for species and CFs. Statistical analysis was conducted by using SPSS software and Microsoft Excel(2010). All the mean values are followed by the standard error $( \pm \mathrm{SE})$.

\section{RESULTS}

\section{Quantitative Analysis}

Regeneration status of different species in both CF. The regeneration status of the Ganesh CF was not prominent as compared to Ramnagar CF. The Ganesh CF contained the seedlings of 13 species from the studied 43 sample plots whereas Ramnagar CF consists of seedlings of 4 species from the studied 20 sample plots. In Ganesh CF, the highest number of seedlings was of Shorea robusta, followed by Mallotus philippensis, Syzygium cumini, and Madhuca indica. Similarly, in Ramnagar $\mathrm{CF}$, the highest number of seedlings was of Shorea robusta, followed by Cassia fistula, Diospyrous melanoxylon, and Terminalia tomentosa. Comparing both CFs, Shorea robusta was the most numerous in both seedling and sapling stages. The total number of seedlings in Ganesh and Ramnagar CF was estimated to be $8591 \pm 288$ and $25000 \pm 1663$ ind. ha ${ }^{-1}$, respectively (Table 1 ).

Similarly, the total number of saplings was found greater in Ramnagar CF compared to Ganesh CF accounting $928 \pm 41$ saplings and $381 \pm 11$ ind. ha ${ }^{-1}$

Table 1: Overview of particular species seedlings regeneration status in both CFs.

\begin{tabular}{|c|c|c|c|c|c|}
\hline \multirow{3}{*}{ S.N. } & \multirow{3}{*}{ Species name } & \multicolumn{4}{|c|}{ Seedlings } \\
\hline & & \multicolumn{2}{|c|}{ Ganesh CF } & \multicolumn{2}{|c|}{ Ramnagar CF } \\
\hline & & Individuals ha ${ }^{-1}$ & $\begin{array}{c}\text { Proportion } \\
(\%)\end{array}$ & Individuals ha ${ }^{-1}$ & $\begin{array}{c}\text { Proportion } \\
(\%)\end{array}$ \\
\hline 1 & Acacia catechu & 74 & 0.86 & 0 & 0.00 \\
\hline 2 & Adina cordifolia & 222 & 2.59 & 0 & 0.00 \\
\hline 3 & Albizia procera & 74 & 0.86 & 0 & 0.00 \\
\hline 4 & Anogeissus latifolia & 370 & 4.31 & 0 & 0.00 \\
\hline 5 & Cassia fistula & 370 & 4.31 & 159 & 0.64 \\
\hline 6 & Diospyrous melanoxylon & 0 & 0.00 & 159 & 0.64 \\
\hline 7 & Ficus spp. & 296 & 3.45 & 0 & 0.00 \\
\hline 8 & Holoptelia integrifolia & 74 & 0.86 & 0 & 0.00 \\
\hline 9 & Madhuca indica & 444 & 5.17 & 0 & 0.00 \\
\hline 10 & Mallotus philippensis & 815 & 9.48 & 0 & 0.00 \\
\hline 11 & Schleichera oleosa & 370 & 4.31 & 0 & 0.00 \\
\hline 12 & Shorea robusta & 4518 & 52.59 & 24522 & 98.09 \\
\hline 13 & Syzygium cumini & 667 & 7.76 & 0 & 0.00 \\
\hline 14 & Terminalia bellerica & 296 & 3.45 & 0 & 0.00 \\
\hline 15 & Terminalia tomentosa & 0 & 0.00 & 159 & 0.64 \\
\hline & Total & 8591 & 100.00 & 25000 & 100.00 \\
\hline
\end{tabular}


Table 2: Overview of particular species saplings regeneration status in both CFs.

\begin{tabular}{|c|c|c|c|c|c|}
\hline \multirow{3}{*}{ S.N. } & \multirow{3}{*}{ Species name } & \multicolumn{4}{|c|}{ Saplings } \\
\hline & & \multicolumn{2}{|c|}{ Ganesh CF } & \multicolumn{2}{|c|}{ Ramnagar CF } \\
\hline & & Individuals ha $^{-1}$ & Proportion (\%) & Individuals ha $^{-1}$ & Proportion (\%) \\
\hline 1 & Acacia catechu & 9 & 2.44 & 0 & 0.00 \\
\hline 2 & Adina cordifolia & 5 & 1.22 & 2 & 0.25 \\
\hline 3 & Anogeissus latifolia & 21 & 5.49 & 33 & 3.51 \\
\hline 4 & Bombax ceiba & 0 & 0.00 & 2 & 0.25 \\
\hline 5 & Cassia fistula & 16 & 4.27 & 0 & 0.00 \\
\hline 6 & Dillenia pentagaina & 0 & 0.00 & 7 & 0.75 \\
\hline 7 & Diospyrous melanoxylon & 0 & 0.00 & 12 & 1.25 \\
\hline 8 & Ficus spp. & 28 & 7.32 & 0 & 0.00 \\
\hline 9 & Holoptelia integrifolia & 9 & 2.44 & 0 & 0.00 \\
\hline 10 & Lagerstroemia parviflora & 9 & 2.44 & 7 & 0.75 \\
\hline 11 & Mallotus philippensis & 98 & 25.61 & 147 & 15.79 \\
\hline 12 & Pterocarpus marsupium & 0 & 0.00 & 2 & 0.25 \\
\hline 13 & Schleichera oleosa & 2 & 0.61 & 9 & 1.00 \\
\hline 14 & Shorea robusta & 174 & 45.73 & 695 & 74.94 \\
\hline 15 & Syzygium cumini & 5 & 1.22 & 5 & 0.50 \\
\hline 16 & Terminalia bellerica & 0 & 0.00 & 7 & 0.75 \\
\hline 17 & Alstonia scholaris & 5 & 1.22 & 0 & 0.00 \\
\hline & Total & 381 & 100.00 & 928 & 100.00 \\
\hline
\end{tabular}

respectively. Therefore, the regeneration status of Ramnagar CF was relatively higher than Ganesh CF (Table $1 \&$ 2). Similarly, the seedlings and saplings of Sal (Shorea robuata) were regular and greater in Ramnagar community forest having higher density and frequency than the Ganesh community forest. It indicates that the seedlings and saplings of Sal (Shorea robusta) have a uniform distribution and the forest structure and composition might not change in coming years.

DBH distributions. While comparing both community forests, Ganesh CF was found contributing the maximum number of trees in diameter class of (10-20) $\mathrm{cm}$ which attributes to 165 tree individuals. Similarly, Ramnagar CF represented

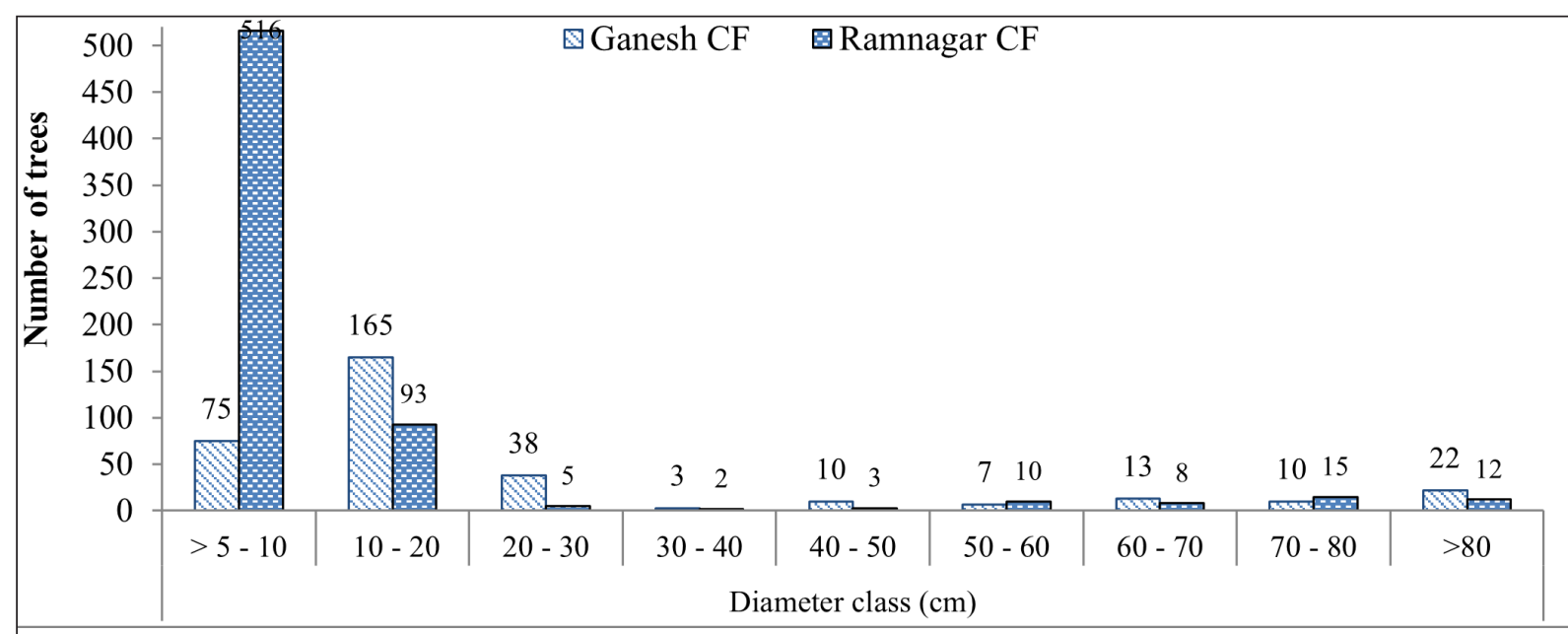

Figure 2: Distribution of DBH in Ganesh and Ramnagar CF. 
the maximum number of trees in diameter class of $(>5-10) \mathrm{cm}$ which accounts for 516 individuals. In both Ganesh and Ramnagar CF, there was the least represented were trees with a diameter exceeding $30 \mathrm{~cm}$ (Figure 2).

Forest structure. The density of seedlings was higher than saplings and trees in both CFs. The presence of a high number of seedlings on the community forest floor signifies the good regeneration potential of the forest site (Figure 3).

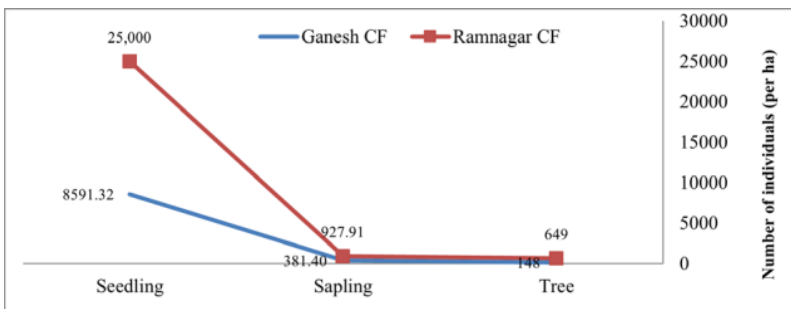

Figure 3: Inverse J-shaped curve indicating the immature condition of community forests.

Community attributes (Importance Value Index). Altogether twenty-two tree species were identified and recorded from the entire sample plots of both community forests. Sixteen tree species with a total individual of 318 trees were identified and measured in Ganesh CF. Likewise, in Ramnagar CF 16 tree species, represented by a total 649 trees were identified and measured. Hence, higher tree density (148 ind. ha ${ }^{-1}$ ) was observed in Ganesh CF followed by 649 ind. ha ${ }^{-1}$ in Ramnagar CF (Table 3). According to the results, the most dominant tree species in Ganesh and Ramnagar community forests were Mallotus philippensis and Shorea robusta accounting for 97.16 and 178.49, respectively. The lowest IVI was for Syzygium cumini (1.70) and Adina cordifolia (1.41) in Ganesh and Ramnagar community forests respectively (Joshi et al. 2019).

\section{Biomass and Carbon estimation}

Aboveground tree biomass (AGTB) and carbon stock. Mean AGTB and carbon stock in Ganesh CF were $163.07 \pm 34.77 \mathrm{t} \mathrm{ha}^{-1}$ and $76.64 \pm 16.34 \mathrm{t}$ $\mathrm{ha}^{-1}$, respectively. Similarly, the AGTB and carbon stock in Ramnagar CF were $347.06 \pm 43.05 \mathrm{t} \mathrm{ha}^{-1}$ and $163.12 \pm 20.23 \mathrm{t} \mathrm{ha}^{-1}$, respectively. As a result, total AGTB and carbon stock were comparatively greater in Ramnagar CF than Ganesh CF (Figure 4). This may be due to the presence of large-sized trees which consequently have higher biomass values (Joshi et al. 2020).
Table 3: Importance Value Index (IVI) of tree species in both $\mathrm{CFs}$

\begin{tabular}{|c|c|c|c|}
\hline \multirow[b]{2}{*}{ S.N. } & \multicolumn{3}{|c|}{ Importance Value Index (I.V.I.) } \\
\hline & Species & $\begin{array}{c}\text { Ganesh } \\
\text { CF }\end{array}$ & $\begin{array}{c}\text { Ramnagar } \\
\text { CF }\end{array}$ \\
\hline 1 & Acacia catechu & 7.24 & - \\
\hline 2 & Adina cordifolia & 30.84 & 1.41 \\
\hline 3 & $\begin{array}{l}\text { Anogeissus } \\
\text { latifolia }\end{array}$ & 17.14 & 10.77 \\
\hline 4 & Bombax ceiba & 3.10 & 4.31 \\
\hline 5 & Cassia fistula & 12.94 & 4.53 \\
\hline 6 & Dalbergia sissoo & - & 1.58 \\
\hline 7 & $\begin{array}{l}\text { Dillenia } \\
\text { pentagaina }\end{array}$ & - & 4.27 \\
\hline 8 & $\begin{array}{l}\text { Diospyrous } \\
\text { melanoxylon }\end{array}$ & - & 3.01 \\
\hline 9 & $\begin{array}{l}\text { Ficus } \\
\text { bengalensis }\end{array}$ & 11.19 & - \\
\hline 10 & Ficus spp. & 4.98 & - \\
\hline 11 & $\begin{array}{l}\text { Holoptelia } \\
\text { integrifolia }\end{array}$ & 7.82 & - \\
\hline 12 & $\begin{array}{l}\text { Lagerstroemia } \\
\text { parviflora }\end{array}$ & 15.15 & 7.39 \\
\hline 13 & Madhuca indica & 2.14 & - \\
\hline 14 & $\begin{array}{l}\text { Mallotus } \\
\text { philippensis }\end{array}$ & 97.16 & 32.79 \\
\hline 15 & $\begin{array}{l}\text { Pterocarpus } \\
\text { marsupium }\end{array}$ & - & 11.34 \\
\hline 16 & $\begin{array}{l}\text { Schleichera } \\
\text { oleosa }\end{array}$ & 13.85 & 4.64 \\
\hline 17 & Shorea robusta & 65.23 & 178.49 \\
\hline 18 & Syzygium cumini & 1.70 & 5.86 \\
\hline 19 & $\begin{array}{l}\text { Terminalia } \\
\text { bellerica }\end{array}$ & 3.56 & 6.6 \\
\hline 20 & $\begin{array}{l}\text { Terminalia } \\
\text { tomentosa }\end{array}$ & - & 21.59 \\
\hline 21 & $\begin{array}{l}\text { Alstonia } \\
\text { scholaris }\end{array}$ & 5.95 & - \\
\hline 22 & $\begin{array}{l}\text { Ziziphus } \\
\text { mauritiana }\end{array}$ & - & 1.42 \\
\hline
\end{tabular}




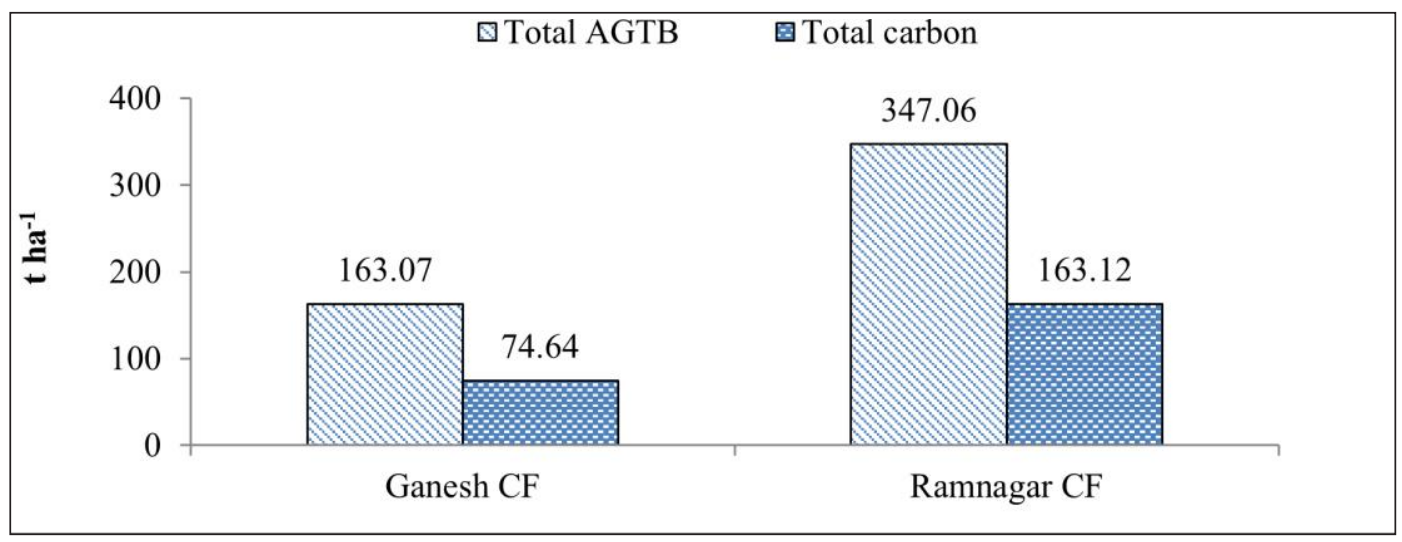

Figure 4: Total AGTB accumulation and carbon stock in both CFs.

Contribution of tree species in carbon stock

In the case of tree layer, Shorea robusta had the highest contribution to the carbon stock of both community-managed forests contributing $38.45 \mathrm{t} \mathrm{ha}^{-1}$ $(50.17 \%)$ in Ganesh CF and $143.10 \mathrm{tha}^{-1}(87.73 \%)$ in Ramnagar CF. Sal (Shorea robusta) was followed by Adina cordifolia (15.67 $\left.\mathrm{t} \mathrm{ha}^{-1}\right)$ and Terminalia tomentosa $\left(14.80 \mathrm{t} \mathrm{ha}^{-1}\right)$ in Ganesh and Ramnagar community forests (Table 4). The least carbon stock was recorded in Syzygium cumini $\left(0.01 \mathrm{t} \mathrm{ha}^{-1}\right)$ and Adina cordifolia $\left(0.003 \mathrm{t} \mathrm{ha}^{-1}\right)$ of Ganesh and Ramnagar community forests. The other tree speciesalso contributed a significantly higher percentage of carbon stock in both community forests (Table 4).

Total species-wise carbon stock among the common species of both Ganesh and Ramnagar community forests statistically showed a significant difference in the total amount of carbon stock in both community forests $(p<0.05)$ (Table 5).

The mean carbon stock of common species in both CFs ranges from 0.02-90.78 $\mathrm{t} \mathrm{ha}^{-1}$ (Table 6). The highest mean value was recorded in Shorea robusta $\left(90.78 \mathrm{t} \mathrm{ha}^{-1}\right)$, followed by Adina cordifolia (7.84 t ha $\left.{ }^{-1}\right)$, Schleichera oleosa $\left(2.47 \mathrm{t} \mathrm{ha}^{-1}\right)$, Mal-

Table 4: The percentage share of species contribution on carbon stock of both CFs.

\begin{tabular}{|c|c|c|c|c|c|c|}
\hline \multirow[b]{2}{*}{ Rank } & \multicolumn{3}{|c|}{ Ganesh CF } & \multicolumn{3}{|c|}{ Ramnagar CF } \\
\hline & Species & $\begin{array}{c}\mathbf{C} \pm \mathbf{S E} \\
\left(\mathbf{t} \mathbf{h a}^{-1}\right)\end{array}$ & $\mathrm{C}(\%)$ & Species & $\begin{array}{l}\mathbf{C} \pm \mathbf{S E} \\
\left(\mathbf{t} \mathbf{h a}^{-1}\right)\end{array}$ & $\mathrm{C}(\%)$ \\
\hline 1 & Shorea robusta & 38.45 & 50.17 & Shorea robusta & 143.1 & 87.73 \\
\hline 2 & Adina cordifolia & 15.67 & 20.45 & Terminalia tomentosa & 14.8 & 9.07 \\
\hline 3 & Schleichera oleosa & 4.88 & 6.37 & Pterocarpus marsupium & 2.66 & 1.63 \\
\hline 4 & Ficus bengalensis & 3.74 & 4.88 & Terminalia bellerica & 1.05 & 0.64 \\
\hline 5 & Holoptelia integrifolia & 2.81 & 3.67 & Mallotus philippensis & 0.97 & 0.59 \\
\hline 6 & Alstonia scholaris & 2.46 & 3.21 & Dalbergia sissoo & 0.16 & 0.1 \\
\hline 7 & Anogeissus. latifolia & 2.46 & 3.21 & Lagerstroemia parviflora & 0.09 & 0.06 \\
\hline 8 & Mallotus philippensis & 2.26 & 2.95 & Dillenia pentagaina & 0.07 & 0.04 \\
\hline 9 & Terminalia bellerica & 1.76 & 2.3 & Cassia fistula & 0.06 & 0.04 \\
\hline 10 & Bombax ceiba & 0.76 & 0.99 & Anogeissus latifolia & 0.05 & 0.03 \\
\hline 11 & $\begin{array}{l}\text { Lagerstroemia parvi- } \\
\text { flora }\end{array}$ & 0.68 & 0.89 & Schleichera oleosa & 0.05 & 0.03 \\
\hline 12 & Cassia fistula & 0.31 & 0.4 & Bombax ceiba & 0.02 & 0.01 \\
\hline 13 & Madhuca indica & 0.19 & 0.25 & Syzygium cumini & 0.02 & 0.01 \\
\hline 14 & Acacia catechu & 0.14 & 0.18 & Diospyrous melanoxylon & 0.01 & 0.01 \\
\hline 15 & Ficus spp. & 0.06 & 0.08 & Ziziphus mauritiana & 0.004 & 0.002 \\
\hline 16 & Syzygium cumini & 0.01 & 0.01 & Adina cordifolia & 0.003 & 0.002 \\
\hline & Total AGTC & $74.64 \pm 16.34$ & 100 & Total AGTC & $163.12 \pm 20.23$ & 100 \\
\hline
\end{tabular}


Table 5: Two way ANOVA test among the common tree species of both CFs

\begin{tabular}{|c|c|c|c|c|c|}
\hline Source of Variation & df & $\begin{array}{c}\text { Sum of } \\
\text { Squares }\end{array}$ & $\begin{array}{c}\text { Mean } \\
\text { Squares }\end{array}$ & F-Calculated & $\boldsymbol{p}$ \\
\hline Replication & 2 & $1,385.70$ & - & - & - \\
\hline CF & 1 & 801.76 & 801.76 & 12.19 & 0.0731 \\
\hline Error (CF) & 2 & 131.53 & 65.77 & - & - \\
\hline Species & 9 & $41,762.44$ & 4640.27 & 16.40 & $<0.0001$ \\
\hline Interaction & 9 & $14,682.79$ & 1631.42 & 5.77 & $<0.0001^{*}$ \\
\hline Error (species) & 36 & $10,188.06$ & 283.00 & - & - \\
\hline Total & 59 & $68,952.28$ & - & - & - \\
\hline
\end{tabular}

Where, ${ }^{*} \mathrm{p}<0.05$ is considered as statistically significant

lotus philippensis $\left(1.62 \mathrm{t} \mathrm{ha}^{-1}\right)$, and minimum in Syzygium cumini $\left(0.02 \mathrm{t} \mathrm{ha}^{-1}\right)$.

\section{DISCUSSION}

\section{Regeneration and other attributes}

The total number of seedlings, saplings, and tree density was comparatively higher in Ramnagar community forest than that of Ganesh community forest. Ramnagar community forest's canopy cover and ground vegetation cover was higher than Ganesh community forests (Joshi et al. 2020). In both community forests, Sal has dominated seedlings and saplings layers. The higher density of Sal species (seedlings and saplings) might be due to the presence of low canopy cover in community forests which allowed the required amount of sunlight to reach the understory of community forests and made the environment favorable for abundant growth of seedlings and saplings of Sal species (Joshi et al. 2020). A high canopy gap fraction (low canopy cover) favors the regeneration of light-demanding species such as Sal (Sapkota

Table 6: Mean carbon stock by common species in both CFs

\begin{tabular}{|c|c|c|c|c|}
\hline \multicolumn{5}{|c|}{ Species-wise AGTC (t ha $\left.{ }^{-1}\right)$} \\
\hline S.N. & Common species & Ganesh CF & Ramnagar CF & Mean \\
\hline 1 & Shorea robusta & 38.45 & 143.1 & 90.78 \\
\hline 2 & Mallotus philippensis & 2.26 & 0.97 & 1.62 \\
\hline 3 & Terminalia bellerica & 1.76 & 1.05 & 1.41 \\
\hline 4 & Anogeissus latifolia & 2.46 & 0.05 & 1.26 \\
\hline 5 & Lagerstroemia parviflora & 0.68 & 0.09 & 0.39 \\
\hline 6 & Syzygium cumini & 0.01 & 0.02 & 0.02 \\
\hline 7 & Schleichera oleosa & 4.88 & 0.05 & 2.47 \\
\hline 8 & Cassia fistula & 0.31 & 0.06 & 0.19 \\
\hline 9 & Adina cordifolia & 15.67 & 0.003 & 7.84 \\
\hline 10 & Bombax ceiba & 0.76 & 0.02 & 0.39 \\
\hline \multicolumn{2}{|r|}{ Mean } & 6.72 & 14.54 & - \\
\hline S.N. & Community forest & CD & SE (d) & $\mathrm{SE}(\mathrm{m})$ \\
\hline 1 & Ganesh CF & NS & 2.09 & 1.48 \\
\hline 2 & Ramnagar CF & 19.78 & 9.71 & 6.87 \\
\hline S.N. & Interaction & CD & SE (d) & SE (m) \\
\hline 1 & Ganesh CF×Species Vs. Ganesh CF×Species & 28.87 & 13.74 & 4.68 \\
\hline 2 & Ganesh $\mathrm{CF} \times$ Species Vs. Ramnagar $\mathrm{CF} \times$ Species & 27.74 & 13.2 & 9.33 \\
\hline
\end{tabular}

Where, $\mathrm{CD}=$ Critical Difference, NS = Not Significant, SE (d) = Standard Error of difference and SE (m) = Standard Error of mean. 
et al. 2009). The abundance and density of seedlings and saplings indicate the regeneration potential of a CF (Pallardy, 2010). Total numbers of individuals were seen to be decreasing from the young regeneration phase to successive development phases in both community forests.

The present study on the regeneration status of forests shows somehow similar pattern to the study from different parts of the country (Table 7). The overall chart was inverse J-shaped indicating the immature condition of the community forests and considered as an ideal condition for regenerating community forests (Chauhan et al. 2008) and also the indication of satisfactory regeneration (Acharya et al. 2007) (Figure 3). Community forest resource inventory guideline (2004) suggested criteria based on the number of seedlings and saplings in a forest for evaluating the regeneration condition of the forest. The regeneration status of the forest is considered to be good if any forest has seedling $>5000$ in number and sapling > 2000 in number per hectare (Pandey et al. 2012). The variation in regeneration pattern of the present study with the below presented results of different researchers may be due to variation in any one of the locality factors like topography, climate, stand, intensity and type of

Table 7: Regeneration status of Sal forests and Sal species under different management categories of Nepal.

\begin{tabular}{|c|c|c|c|c|c|c|c|c|}
\hline \multirow{2}{*}{ Forest type (Location) } & \multirow{2}{*}{$\begin{array}{l}\text { Management } \\
\text { type }\end{array}$} & \multicolumn{3}{|c|}{$\begin{array}{c}\text { Forest regeneration } \\
\text { (ind. ha } \text { he }^{-1} \text { ) }\end{array}$} & \multicolumn{3}{|c|}{ Sal regeneration (ind. ha ${ }^{-1}$ ) } & \multirow{2}{*}{ Reference } \\
\hline & & Seedling & Sapling & Tree & Seedling & Sapling & Tree & \\
\hline $\begin{array}{l}\text { Tropical Sal forest } \\
\text { (Ganesh CF, Kanchanpur) }\end{array}$ & $\mathrm{CM}$ & 8591 & 381 & 148 & 4518 & 174 & 20 & This study \\
\hline $\begin{array}{l}\text { Tropical Sal forest } \\
\text { (Ramnagar CF, } \\
\text { Kanchanpur) }\end{array}$ & $\mathrm{CM}$ & 25000 & 928 & 649 & 24522 & 695 & 449 & This study \\
\hline Tropical Sal (Rupandehi) & Collaborative & $\begin{array}{l}13035- \\
21022\end{array}$ & (NA) & $\begin{array}{l}66- \\
552\end{array}$ & $\begin{array}{l}6445- \\
13977\end{array}$ & $\begin{array}{l}1055- \\
3022\end{array}$ & NA & $\begin{array}{l}\text { Awasthi et al. } \\
\text { (2015) }\end{array}$ \\
\hline $\begin{array}{l}\text { Tropical \& sub-tropical } \\
\text { Sal (Banke NP) }\end{array}$ & GM & $\begin{array}{l}6367- \\
59236 \\
\end{array}$ & $260-5809$ & $\begin{array}{l}83- \\
634\end{array}$ & 27153 & 201 & 46 & Napit (2015) \\
\hline Terai (FWP) & NA & 40261 & 1463 & NA & NA & NA & NA & $\begin{array}{c}\text { DFRS (2014 } \\
\text { a, b) }\end{array}$ \\
\hline Churia (FWP) & NA & 12661 & 491 & NA & NA & NA & NA & $\begin{array}{c}\text { DFRS (2014 } \\
\text { a, b) }\end{array}$ \\
\hline Terai (NL) & $\mathrm{CM}$ & 25469 & 1866 & NA & NA & NA & NA & $\begin{array}{l}\text { DFRS }(2014 \\
\text { a, b) }\end{array}$ \\
\hline Churia (NL) & $\mathrm{CM}$ & 22294 & 1216 & NA & NA & NA & NA & $\begin{array}{c}\text { DFRS (2014 } \\
\mathrm{a}, \mathrm{b}) \\
\end{array}$ \\
\hline Terai (NL) & NA & 29649 & 1662 & 583 & 18686 & 358 & 188 & $\begin{array}{c}\text { DFRS (2014 } \\
\text { a, b) }\end{array}$ \\
\hline Churia (NL) & NA & 19805 & 958 & 731 & 12140 & 227 & 223 & $\begin{array}{c}\text { DFRS (2014 } \\
\mathrm{a}, \mathrm{b})\end{array}$ \\
\hline Tropical Sal (Palpa) & GM & NA & 3438 & $3-209$ & 4375 & 2563 & 209 & $\begin{array}{l}\text { Basyal et al. } \\
\text { (2011) }\end{array}$ \\
\hline Sal (Surkhet) & $\mathrm{CM}$ & NA & NA & NA & 6758 & 4484 & 962 & $\begin{array}{l}\text { Shrestha } \\
(2009)\end{array}$ \\
\hline Sal (Surkhet) & Protected & NA & NA & NA & 4422 & 422 & 1008 & $\begin{array}{l}\text { Shrestha } \\
\text { (2009) }\end{array}$ \\
\hline $\begin{array}{l}\text { Tropical Sal (Bardia NP, } \\
\text { Suklaphanta NP \& } 2 \text { CFs } \\
\text { from Kanchanpur) }\end{array}$ & $\mathrm{CM} \& \mathrm{GM}$ & 79072 & 1798 & 220 & 70462 & 1431 & 64 & $\begin{array}{l}\text { Timilsina et al. } \\
\text { (2007) }\end{array}$ \\
\hline $\begin{array}{l}\text { Inner Terai Sal (Chitwan } \\
\& \text { Nawalparasi) }\end{array}$ & $\mathrm{CM}$ & NA & NA & NA & 43000 & 2974 & 192 & Kandel (2007) \\
\hline Tropical Sal (Bardiya) & GM & NA & NA & NA & 11185 & 321 & 95 & $\begin{array}{l}\text { Giri et al. } \\
\text { (1999) }\end{array}$ \\
\hline
\end{tabular}

Where, NA = Not available, $\mathrm{CM}=$ Community managed, $\mathrm{GM}=$ Government managed, $\mathrm{NP}=$ National Park, NL $=\mathrm{Na}-$ tional Level and FWP $=$ Far-West Province. 
disturbances, and soil nutrients of the study site. Different studies like Sapkota et al. (2009); Gautam and Devoe (2006) showed regeneration of Sal was either positively or negatively affected by these factors.

\section{Community attributes}

The Importance Value Index (IVI) of Mallotus philippensis (97.16) and Shorea robusta (178.49) was found highest in Ganesh and Ramnagar community forests, respectively. A high IVI value of a species indicated its dominance and ecological success, its good power of regeneration, and greater ecological amplitude (Shameem \& Kangroo, 2011). This indicates that Mallotus philippensis and Shorea robusta were the most important and dominant tree species in Ganesh and Ramnagar community forests respectively which utilizes most of the forest area and resources. The disappearance of previously dominant species like Shorea robusta and the appearance of Mallotus philippensis with other associate species as a dominant character at their recruitment stage has been commonly observed as a result of severe forest degradation or disturbance activities (Onaindia et al. 2004).

\section{Carbon stock and Sal forest}

The standing carbon stock of trees varies with the successional stage of the forest and the carbon sequestration potential depends on the forest type, age of forest, size of trees, density of trees, and stand condition (Brown et al,, 1989; Dixon et al. 1994; Joshi \& Singh 2020). With the increasing age of forest, the carbon sequestered by plants is stored as biomass.

Many trees in the studied community forests reach DBH of less than $20 \mathrm{~cm}$. According to Johnson \& Coburn (2010), if trees in forests are well stocked, it typically sequestrates carbon at a maximum rate between the age of 10,20, and 30 years old. As an indicator, at the age of 30 years, about 200-520 tons of carbon dioxide $\left(\mathrm{CO}_{2}\right)$ are sequestered per ha in forests with productivity ranging from low to high. So, the studied community forests might have the potentiality to sequestrate more carbon. Carbon sequestration depends on the rate of annual growth of forests, positively correlated with age. The old forests with over mature stand have high carbon stock but the rate of carbon sequestration is low because of annual growth of mature tree has less than young stand. Among the studied community forests, Ramnagar CF got higher tree biomass stock than Ganesh $\mathrm{CF}$. The aboveground tree biomass and carbon stock in Ganesh CF were $163.07 \mathrm{tha}^{-1}$ and $76.64 \mathrm{t} \mathrm{ha}^{-1}$, respectively which was lower than in Ramnagar CF (biomass $347.06 \mathrm{t} \mathrm{ha}^{-1}$ and carbon $163.12 \mathrm{t} \mathrm{ha}^{-1}$ ). The FRA report 2014 shows that the total carbon stock from the forest of Terai region to be $89.18 \mathrm{t} \mathrm{ha}^{-1}$, Sal being the highest contributor on carbon stock, a similar result has been shown by our study as Sal was the highest contributor of $\mathrm{C}$-stock in the tree layer with $50.17 \%\left(38.5 \mathrm{t} \mathrm{ha}^{-1}\right)$ and $87.73 \%\left(143.10 \mathrm{t} \mathrm{ha}^{-1}\right)$ in both Ganesh and Ramnagar community forests, respectively. The carbon stock contribution of Sal species in Ramnagar CF followed the patterns from the Sal-dominated two CFs of Gorkha where Sal contributed 95\% \& 86\% in C-stock (Neupane \& Sharma, 2014). In contrary to this, Gaihre (2015) found that Sal contributed $64.5 \%$ \& $44.7 \%$ in C-stock in two community-managed forests of Tanahun district which was similar to the results of Ganesh CF. In the Ramnagar community forests (Present study) the difference between the density of Sal and other species was higher whereas in the study of Gaihre (2015) and Ganesh community forests (present study) difference between Sal density and density of other species were relatively low.

\section{CONCLUSIONS}

The carbon stock increased with the increase in sustainable management duration of forests while the density of seedlings, saplings, and trees in studied CFs were in the following order: seedlings $>$ saplings $>$ trees. Therefore, the hypothesis that the biomass C-stock of the community-managed forest increases with the management duration and community-managed forests has a good regeneration status had been accepted. The number of seedling, sapling, and tree were more in Ramnagar community forests than Ganesh community forests. The total number (density) of Sal seedlings and saplings were higher than other associated species in both Community Forests. Sal was followed by Mallotus philippensis, Syzygium cumini, Anogeissus latifolia, and Madhuca indica. Shorea robusta was the most dominant species and showed a significant contribution to the carbon stock of both community forests $(50.17 \%$ in Ganesh CF and $87.73 \%$ in Ramnagar CF). There was a significant contribution of other species like Adina cordifolia, Terminalia tomentosa, Schleichera oleosa, and Ficus bengalensis. The community management had a significant positive impact on regeneration and carbon stock of forests indicated carbon sequestration has a positive impact on biodiversity, which results 
in the productivity of the forest but both community forests need more measures to enrich the tree diversity. Hence, this study strongly recommends the application of sustainable forest management activities, as practiced under community forest management. And these community-managed forests should be initiated for inclusion in REDD+ scheme so that they can get carbon credit benefits which will help in the improvement of forest conditions and livelihoods of the local community.

\section{ACKNOWLEDGEMENTS}

This article is a part of the first author's M.Sc. (Forestry) thesis. The authors would like to acknowledge Divisional Forest Office, Kanchanpur Nepal, and the CFUG members of Ganesh and Ramnagar community forests for their help and support during the fieldwork.

\section{REFERENCES}

Acharya, K. P. (2002) Twenty-four years of community forestry in Nepal. International Forestry Review, 4(2), 149 -56. DOI: https://doi.org/10.1505/ IFOR.4.2.149.17447

Acharya, K. P. (2003) Changing the strategy for community forestry in Nepal: The case for active management. Journal of Forest Policy, 10(1), 43-50.

Acharya, K.P., Khadka, S., Lekhak, H.D., Chaudhary, R.P. \& Vetaas, O.R. (2007) Species composition and regeneration of coniferous forest in Manang. In: R.P. Chaudhary, T.H. Aase, O.R. Vetaas and B.P. Subedi (eds.) Local Effects of Global Changes in the Himalayas: Manang, Nepal (pp. 131-138). Tribhuvan: Tribhuvan University and Bergen: University of Bergen.

Adhikari, S. (2016). Growing money from carbon. Kathmandu. Retrieved from http://www.communityredd. net (Accessed $5^{\text {th }}$ July 2020).

Awasthi, N., Aryal, K., Chhetri, B.B.K., Bhandari, S.K., Khanal, Y., Gotame, P. et al. (2020) Reflecting on species diversity and regeneration dynamics of scientific forest management practices in Nepal. Forest Ecology and Management, 474, 118378. DOI: https://doi. org/10.1016/j.foreco.2020.118378

Awasthi, N., Bhandari, S. K. \& Khanal, Y. (2015) Does scientific forest management promote plant species diversity and regeneration in Sal (Shorea robusta) forest? A case study from Lumbini collaborative forest, Rupandehi, Nepal. Banko Janakari, 25(1), 20-29. DOI: https://doi.org/10.3126/banko.v25i1.13468
Baboo, B., Sagar, R., Bargali, S.S. \& Verma, H. (2017) Tree species composition, regeneration and diversity of an Indian dry tropical forest protected area. Tropical Ecology, 58(2), 409-423.

Bargali, K., Joshi, B., Bargali, S.S. \& Singh, S.P. (2014) Diversity within Oaks. International Oaks, 25, 57-70.

Bargali, S. S. \& Singh, R. P. (1997) Pinus patula Plantations in Kumaun Himalaya. II Nutrient Dynamics. Journal of Tropical Forest Science, 10(1), 101-114.

Bargali, S.S. (1994) Forest floor development in Eucalyptus tereticornis Sm. plantations in a part of Central Himalayan Terai belt. Range Management \& Agroforestry, 15(1), 61-68.

Bargali, S.S. (1995) Efficiency of nutrient utilization in an age series of Eucalyptus tereticornis plantations in the Terai belt of Central Himalaya. Journal of Tropical Forest Science, 7(3), 383-390.

Bargali, S.S. (1996) Weight loss and N release in decomposing wood litter in a eucalypt plantation age series. Soil Biology and Biochemistry, 28(4-5), 699-702. DOI: https://doi.org/10.1016/0038-0717(95)00143-3

Bargali, S.S., Singh, R.P. \& Singh, S.P. (1992) Structure and function of an age series of eucalypt plantations in Central Himalaya, II. Nutrient dynamics. Annals of Botany, 69(5), 413-421. DOI: 10.1093/oxfordjournals.aob.a088362

Bargali, S.S., Singh, S.P. \& Singh, R.P. (1993) Patterns of weight loss and nutrient release from decomposing leaf litter in an age series of eucalypt plantations. Soil Biology and Biochemistry, 25(12), 1731-1738. DOI: https://doi.org/10.1016/0038-0717(93)90177-D

Basyal, S., Lekhak, H.D. \& Devkota, A. (2011) Regeneration of Shorea robusta Gaertn in tropical forest of Palpa district, central Nepal. Scientific World, 9(9), 53-56. DOI: https://doi.org/10.3126/sw.v9i9.5519

Bhatta, M. \& Joshi, R. (2020) Analysis of Human-Wildlife Conflict in Buffer Zone Area: A Case Study of Shuklaphanta National Park, Nepal. Grassroots Journal of Natural Resources, 3(3), 28-45. DOI: https://doi. org/10.33002/nr2581.6853.03033

Bhattarai, K. \& Conway, D. (2008) Evaluating land use dynamics and forest cover change in Nepal's Bara district (1973-2003). Human Ecology, 36(1), 81-95. DOI: https://doi.org/10.1007/s10745-007-9144-3

Brown, S., Gillespie, A.J. \& Lugo, A.E. (1989) Biomass estimation methods for tropical forests with applications to forest inventory data. Forest Science, 35(4), 881-902. DOI: https://doi.org/10.1093/forestscience/35.4.881

Brown, S., Sathaye, J., Cannell, M. \& Kauppi, P. E. (1996) Mitigation of carbon emissions to the atmosphere by 
forest management. The Commonwealth Forestry Review, 75(1), 80-91.

Ceccon, E., Sánchez, S. \& Campo, J. (2004) Tree seedling dynamics in two abandoned tropical dry forests of differing successional status in Yucatán, Mexico: a field experiment with $\mathrm{N}$ and $\mathrm{P}$ fertilization. Plant Ecology, 170(2), 277-285. DOI: https://doi.org/10.1023/ B:VEGE.0000021699.63151.47

Chand, H. B., Singh, H. \& Chhetri, R. (2018) Carbon Sequestration Potential in Sahid Smriti Community Forest: A Case Study of Terai Region of Nepal. In: International Conference on Agriculture and Allied Sciences: The Productivity, Food Security and Ecology (pp. 108-113).

Chaturvedi, R.K., Raghubanshi, A.S. \& Singh, J.S. (2012) Effect of grazing and harvesting on diversity, recruitment and carbon accumulation of juvenile trees in tropical dry forests. Forest Ecology and Management, 284, 152-162. DOI: https://doi.org/10.1016/j. foreco.2012.07.053

Chauhan, P.S., Negi, J.D.S., Singh,L., \& Manhas, R.K. (2008) Regeneration status of Sal forests of Doon Valley. Annals of Forestry, 16(2), 178-182.

Chave, J., Andalo, C., Brown, S., Cairns, M.A., Chambers, J.Q., Eamus, D. et al. (2005) Tree allometry and improved estimation of carbon stocks and balance in tropical forests. Oecologia, 145: 87-99. DOI: https:// doi.org/10.1007/s00442-005-0100-X

Chhetri, B.B.K., Lund, J.F. \& Nielsen, Ø.J. (2012) The public finance potential of community forestry in Nepal. Ecological Economics, 73, 113-121. DOI: https://doi.org/10.1016/j.ecolecon.2011.09.023

Condit, R., Hubbell, S.P. \& Foster, R.B. (1996) Changes in tree species abundance in a neotropical forest: impact of climate change. Journal of Tropical Ecology, 12, 231-256.

Curtice, J. (1959) The Vegetation of Wisconsin: An ordination of plant communities. Madison: The University of Wisconsin Press.

DFRS. (2014a) Terai forests of Nepal (2010-2012). Forest resource assessment Nepal project. Kathmandu: Department of Forest Research and Survey, Ministry of Forests and Soil Conservation, Babar Mahal..

DFRS. (2014b) Churia forests of Nepal (2011-2013). Forest resource assessment Nepal project. Kathmandu: Department of Forest Research and Survey, Ministry of Forests and Soil Conservation, Babar Mahal..

DFRS. (2015) State of Nepal's Forests. Kathmandu: Forest Resource Assessment (FRA) Nepal, Department of Forest Research and Survey (DFRS). DOI: https:// doi.org/978-9937-8896-3-6
Dixon, R.K., Solomon, A.M., Brown, S., Houghton, R.A., Trexier, M.C. \& Wisniewski, J. (1994) Carbon pools and flux of global forest ecosystems. Science, 263(5144), 185-190. DOI: 10.1126/science.263.5144.185

Figueroa-Rangel, B.L. \& Olvera-Vargas, M. (2000) Regeneration patterns in relation to canopy species composition and site variables in mixed oak forests in the Sierra de Manantlán Biosphere Reserve, Mexico. Ecological Research, 15(3), 249-261. DOI: https://doi.org/10.1046/j.1440-1703.2000.00346.x

Gautam, K.H. \& Devoe, N.N. (2006) Ecological and anthropogenic niches of sal (Shorea robusta Gaertn. f.) forest and prospects for multiple-product forest management-a review. Forestry, 79(1), 81-101. DOI: https://doi.org/10.1093/forestry/cpi063

Giri, A., Aryal, B., Bhattarai, B., Ghimire, S.K., Shrestha, K.K. \& Jha, P.K. (1999) Vegetation composition, biomass production and regeneration in Shorea robusta forests in the Royal Bardia National Park, Nepal. Nepal Journal of Science and Technology, 1(1), 47-56.

Herrmann, T.M. (2006) Indigenous knowledge and management of Araucaria araucana forest in the Chilean Andes: implications for native forest conservation. Biodiversity \& Conservation, 15(2), 647-662. DOI: https://doi.org/10.1007/s10531-005-2092-6

Himani, K., Kiran, B., Bargali, S.S. \& Rawat, Y.S. (2017) Plant diversity, regeneration status and standing biomass under varied degree of disturbances in temperate mixed oak-conifer forest, Kumaun Himalaya. International Journal of Ecology and Environmental Sciences, 43(4), 331-345.

Hobley, M. (1996) Participatory forestry: the process of change in India and Nepal. London: Overseas Development Institute.

IPCC, (2007) Climate Change 2007: The Physical Science Basis. Contribution of Working group I to the Fourth Assessment Report of the Intergovernmental Panel on Climate. Change. Cambridge-New-York: Cambridge University Press

Johnson, I. \& Coburn, R. (2010) Trees for carbon sequestration. Prime Facts, Industry and Investment, NSW Government.Joshi, R., Chhetri, R. \& Yadav, K. (2019) Vegetation Analysis in Community Forests of Terai Region, Nepal. International Journal of Environmental Science 8(3), 68-82. DOI: https://doi.org/10.3126/ ije.v8i3.26667

Joshi, R., Chhetri, R. \& Yadav, K. (2019) Vegetation Analysis in Community Forests of Terai Region, Nepal. International Journal of Environment, 8(3), 6882. DOI: https://doi.org/10.3126/ije.v8i3.26667 
Joshi, R. \& Singh, H. (2020) Carbon sequestration potential of disturbed and non-disturbed forest ecosystem: A tool for mitigating climate change. African Journal of Environmental Science and Technology, 14(11),385393. DOI: https://doi.org/10.5897/AJEST2020.2920

Joshi, R., Singh, H., Chhetri, R. \& Yadav, R. (2020) Assessment of Carbon Sequestration Potential in Degraded and Non-Degraded Community Forests in Terai Region of Nepal. Journal of Forest and Environmental Science, 36(2), 113-121. DOI: https://doi. org/10.7747/JFES.2020.36.2.113

Joshi, R., Singh, H., Chhetri, R., Poudel, S. \& Rijal, S. (2021) Carbon sequestration potential of community forests: A comparative analysis of soil organic carbon stock in community managed forests of Far-Western Nepal. Eurasian Journal of Soil Science, 10(2), 96-104. DOI: https://doi.org/10.18393/ ejss.825066

Kandel, D.R. (2007) Vegetation structure and regeneration of Sal (Shorea robusta Gaertn.) in community managed forests of inner Terai, central Nepal. M.Sc Thesis, Central Department of Botany, Tribhuvan University, Kirtipur, Kathmandu, Nepal.

Khumbongmayum, A.D., Khan, M.L. \& Tripathi, R.S. (2005) Survival and growth of seedlings of a few tree species in the four sacred groves of Manipur, Northeast India. Current Science, 88(11), 1781-1788.

Lutze, M., Ades, P. \& Campbell, R. (2004) Review of measures of site occupancy by regeneration. Australian Forestry, 67(3), 164-171. DOI: https://doi.org/10 $.1080 / 00049158.2004 .10674930$

MacDicken, K.G. (1997) A guide to monitoring carbon storage in forestry and agroforestry projects. Arlington: Winrock International Institute for Agricultural Development.

Malik, Z.A. \& Bhatt, A.B. (2016) Regeneration status of tree species and survival of their seedlings in Kedarnath Wildlife Sanctuary and its adjoining areas in Western Himalaya, India. Tropical Ecology, 57(4), $677-690$.

Måren, I.E., Karki, S., Prajapati, C., Yadav, R.K. \& Shrestha, B.B. (2015) Facing north or south: Does slope aspect impact forest stand characteristics and soil properties in a semiarid trans-Himalayan valley? Journal of Arid Environments, 121, 112-123. DOI: https:// doi.org/10.1016/j.jaridenv.2015.06.004

Mishra, A.K., Bajpai, O., Sahu, N., Kumar, A., Behera, S.K., Mishra, R.M. \& Chaudhary, L.B. (2013) Study of plant regeneration potential in tropical moist deciduous forest in northern India. International Journal of Environment, 2(1), 153-163. DOI: https://doi. org/10.3126/ije.v2i1.9218
MoFE. (2019) Forest Act 2019. Kathmandu: Ministry of Forests and Soil Conservation (MoFSC), Government of Nepal.

MoFSC. (1993) Forest Act 1993. Kathmandu: Ministry of Forests and Soil Conservation (MoFSC), Government of Nepal.

MoFSC. (1995) Forest Regulation 1995. Kathmandu: Ministry of Forests and Soil Conservation (MoFSC), Government of Nepal.

MoFSC. (2010) Forest Carbon Estimation Guideline. Singh durbar, Kathmandu: Ministry of Forests and Soil Conservation.

Mourya, N.R., Bargali, K. \& Bargali, S.S. (2019) Impacts of Coriaria nepalensis colonization on vegetation structure and regeneration dynamics in a mixed conifer forest of Indian Central Himalaya. Journal of Forestry Research, 30(1), 305-317. DOI: 10.1007/ s11676-018-0613-X

Napit, R. (2015) Species Diversity, Forest Community Structure and Regeneration in Banke National Park. Nepal Journal of Science and Technology, 16(1), 17-30. DOI: https://doi.org/10.3126/njst.v16i1.14354 Nguyen, T.T. \& Baker, P.J. (2016) Structure and composi- tion of deciduous dipterocarp forest in Central Viet- nam: patterns of species dominance and regeneration failure. Plant Ecology \& Diversity, 9(5-6), 589-601. DOI: https://doi.org/10.1080/17550874.2016.121026 1

Ojha, H., Timsina, N. \& Khanal, D. (2007) How are forest policy decision made in Nepal? Journal of Forest and Livelihoods, 6(1), 1-17.

Onaindia, M., Dominguez, I., Albizu, I., Garbisu, C. \& Amezaga, I. (2004) Vegetation diversity and vertical structure as indicators of forest disturbance. Forest Ecology and Management, 195(3), 341-354. DOI: https://doi.org/10.1016/j.foreco.2004.02.059

Pallardy, S. G. (2010). Physiology of woody plants. San Diego: Academic Press.

Pandey, H.P., Maren, I.E. \& Dutta, I.C. (2012). REDD+ in community forests, western Nepal: A case from Gorkha district, central Himalaya. Chisinau: LAMBERT Academic Publishing.

Pathak, B. R., Yi, X. \& Bohara, R. (2017) Community based forestry in Nepal: Status, issues and lessons learned. International Journal of Sciences, 6(3), 119129. DOI: https://doi.org/10.18483/ijsci.1232

Sagar, R., Raghubanshi, A.S. \& Singh, J. S. (2008) Comparison of community composition and species diversity of understorey and overstorey tree species in a dry tropical forest of northern India. Journal of Environmental Management, 88(4), 1037-1046. DOI: https://doi.org/10.1016/j.jenvman.2007.05.013 
Saner, P., Loh, Y.Y., Ong, R.C. \& Hector, A. (2012) Carbon stocks and fluxes in tropical lowland dipterocarp rainforests in Sabah, Malaysian Borneo. PloS One, 7(1), e29642. DOI: https://doi.org/10.1371/journal.pone.0029642

Sapkota, I.P., Tigabu, M. \& Odén, P.C. (2009) Spatial distribution, advanced regeneration and stand structure of Nepalese Sal (Shorea robusta) forests subject to disturbances of different intensities. Forest Ecology and Management, 257(9), 1966-1975. DOI: https:// doi.org/10.1016/j.foreco.2009.02.008

Saxena, A.K., Singh, S.P. \& Singh, J. S. (1984) Population structure of forests of Kumaun Himalaya: Implications for management. Journal of Environmental Management, 19(4): 307-324.

Shameem, S.A. \& Kangroo, I.N. (2011) Comparative assessment of edaphic features and phytodiversity in lower Dachigam National Park, Kashmir Himalaya, India. African Journal of Environmental Science and Technology, 5(11): 972-984.

Shrestha, T. (2009) Vegetation composition and regeneration of Shorea robusta Gaertn. in community managed and protected forests of Surkhet district. MSc Thesis, Central Department of Botany, Tribhuvan University, Kirtipur, Kathmandu, Nepal.

Singh J.S., Gupta S.R. \& Singh S.P. (2006) Ecology, environment and resource conservation. New Delhi: Anamaya publishers.

Singh, J. S. (1992) Forests of Himalaya: Structure, functioning and impact of man. Kanpur: Gyanodaya Prakashan.

Singh, J.S. (2002) The biodiversity crisis: a multifaceted review. Current Science, 82(6), 638-647.
Stork, N.E. (2010) Re-assessing current extinction rates. Biodiversity and Conservation, 19(2), 357-371. DOI: https://doi.org/10.1007/s10531-009-9761-9

Timilsina, N., Ross, M.S. \& Heinen, J.T. (2007) A community analysis of sal (Shorea robusta) forests in the western Terai of Nepal. Forest Ecology and Management, 241(1-3), 223-234. DOI: https://doi. org/10.1016/j.foreco.2007.01.012

Tripathi, R.S. \& Khan, M.L. (2007) Regeneration dynamics of natural forests. Proceedings of the Indian National Science Academy, 73(3), 167-195.

UNEP. (2001) Executive Summary. In: India: State of the Environment Report 2001 (pp. 1-6). New Delhi: UNEP-TERI-MEOEF.

UNFCCC. Paris, COP 21, (2010). Information Hub. Retrieved from http://unfccc.int/focus/climate_finance/ items/7001.php (Accessed on 16th April 2020).

Ward, J.S., Worthley, T.E., Smallidge, P.J. \& Bennett, K.P. (2006) Northeastern forest regeneration handbook. A guide for forest owners, harvesting practitioners, and public officials. Newtown Square: USDA Forest Service, Northeastern Area State and Private Forestry.

Wei, X., Shao, M., Gale, W. and Li, L. (2014) Global pattern of soil carbon losses due to the conversion of forests to agricultural land. Scientific Reports, 4(1), 1-6. DOI: https://doi.org/10.1038/srep04062

Zhou, G., Liu, S., Li, Z., Zhang, D., Tang, X., Zhou, C., et al. (2006). Old-growth forests can accumulate carbon in soils. Science, 314(5804), 1417-1417. DOI: https://doi.org/10.1126/science.1130168

Zobel, D.B., Jha, P.K., Behan, M.J. \& Yadav, U.K.R. (1987) A practical manual for ecology. Bagbazar, Kathmandu: Ratna Book Distributors. 